\title{
Ace Lake: three decades of research on a meromictic, Antarctic lake
}

\author{
Johanna Laybourn-Parry • Elanor M. Bell
}

Received: 15 November 2013/Revised: 22 July 2014/ Accepted: 24 July 2014/Published online: 10 August 2014

(C) The Author(s) 2014. This article is published with open access at Springerlink.com

\begin{abstract}
Ace Lake (Vestfold Hills, Antarctica) has been investigated since the 1970s. Its close proximity to Davis Station has allowed year-long, as well as summer only, investigations. Ace Lake is a saline meromictic (permanently stratified) lake with strong physical and chemical gradients. The lake is one of the most studied lakes in continental Antarctica. Here, we review the current knowledge of the history, the physical and chemical environment, community structure and functional dynamics of the mixolimnion, littoral benthic algal mats, the lower anoxic monimolimnion and the sediment within the monimolimnion. In common with other continental meromictic Antarctic lakes, Ace Lake possesses a truncated food web dominated by prokaryote and eukaryote microorganisms in the upper aerobic mixolimnion and an anaerobic prokaryote community in the monimolimnion, where methanogenic Archaea, sulphate-reducing and sulphur-oxidizing bacteria occur. These communities are functional in winter at subzero temperatures, when mixotrophy plays an important role in survival in dominant photosynthetic eukaryotic microorganisms in the mixolimnion. The productivity of Ace Lake is comparable to other saline lakes in the Vestfold Hills, but higher than that seen in the more southerly McMurdo Dry Valley lakes. Finally, we identify gaps in the current knowledge and avenues that demand further investigation, including comparisons with analogous lakes in the north polar region.
\end{abstract}

\footnotetext{
J. Laybourn-Parry ( $\bowtie)$

Bristol Glaciology Centre, School of Geographical Sciences, University of Bristol, Bristol BS8 1SS, UK

e-mail: Jo.Laybourn-Parry@ bristol.ac.uk

E. M. Bell

Australian Antarctic Division, Channel Highway, Kingston, TAS 7050, Australia
}

Keywords Antarctic $\cdot$ Saline lakes $\cdot$ Microbial dynamics · Mixolimnion · Monimolimnion · Ace Lake

\section{History of Ace Lake}

Ace Lake is situated in the Vestfold Hills $\left(68^{\circ} 28^{\prime} \mathrm{S}\right.$, $\left.78^{\circ} 11^{\prime} \mathrm{E}\right)$ in Princess Elizabeth Land, East Antarctica (Fig. 1). The Vestfold Hills is a low-lying, ice-free coastal area of approximately $400 \mathrm{~km}^{2}$ that contains around 300 lakes and ponds that range from freshwater, through hyposaline and saline, to hypersaline, formed in glacially scoured basins. Approximately 21 of the investigated saline lakes are meromictic having permanently stratified water columns with strong physical and chemical gradients (Gibson 1999). Ace Lake is one of these meromictic lakes and is also one of the most studied lakes in the Vestfold Hills; the lake has been a site of limnological investigation since the late 1970s (e.g. Burton and Barker 1979; Burke and Burton 1988; Volkman et al. 1988; Heath 1988; Lauro et al. 2011; Laybourn-Parry and Wadham 2014). Davis Station was established in the Vestfold Hills in 1957, during the International Geophysical year. This permanently manned research station has facilitated year-long and summer only investigations that together have established a substantial database on the limnology of Ace Lake. A review of Ace Lake was published in 1999 (Rankin et al. 1999). In the succeeding years considerably more data, particularly long-term, process-related data, have provided a more detailed picture of the structure and functioning of the lake, information that this article reviews.

The palaeolimnology of Ace Lake has been well documented. Studies based on diatom, protozoan and animal fossils, $\delta^{13} \mathrm{C}$ and $\delta^{18} \mathrm{O}$ analyses, sulphur chemistry and radiocarbon dating have allowed a detailed picture of the 
Fig. 1 Vestfold Hills showing position of Ace Lake

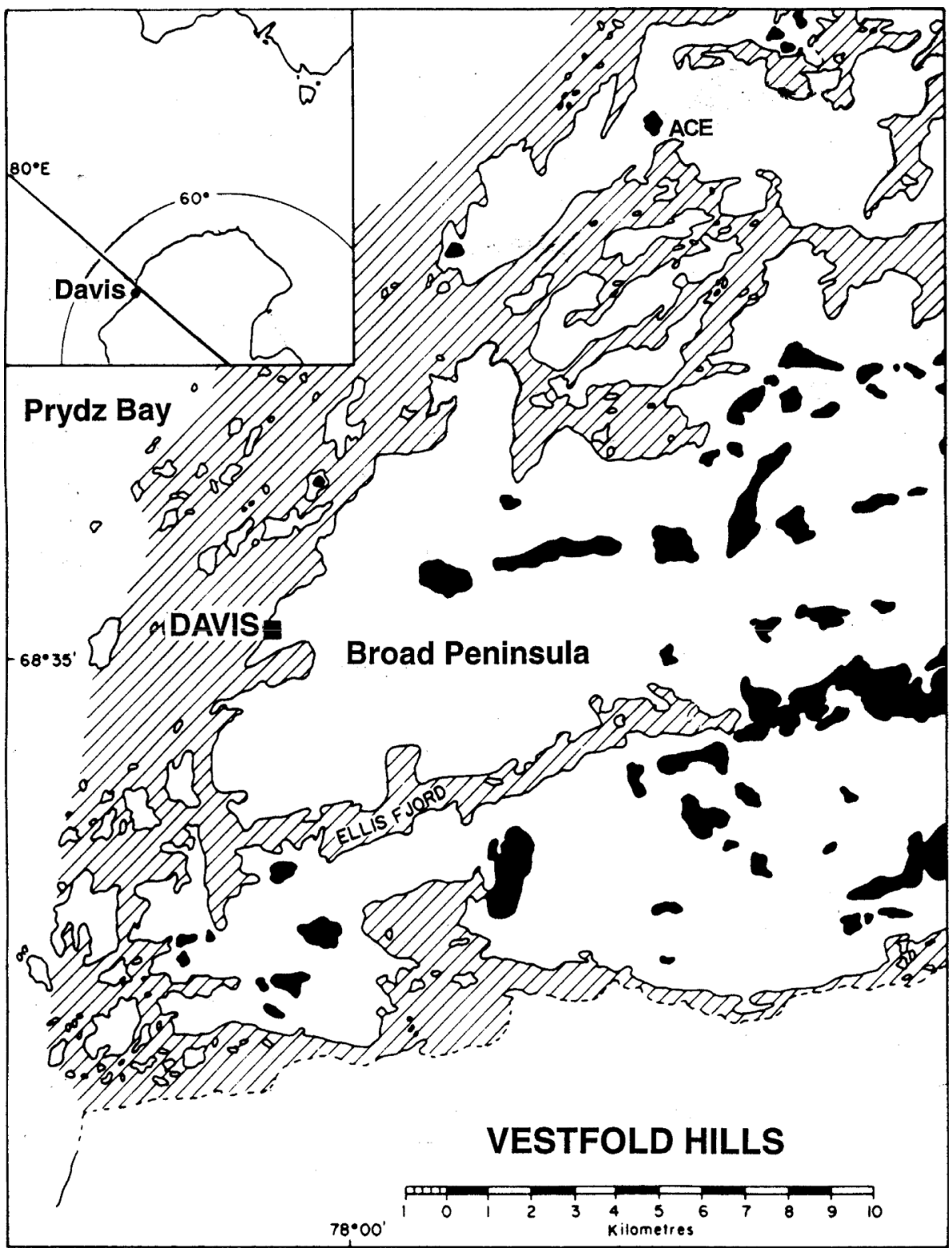

evolution of Ace Lake to be constructed (Burton and Barker 1979; Bird et al. 1991; Fulford-Smith and Sikes 1996; Zwartz et al. 1998; Roberts and McMinn 1999; Cromer et al. 2005). The lake appears to have undergone several phases of meromixis interspersed with phases of mixis. The lake was originally freshwater; following the retreat of the polar ice sheet at the end of the last glacial maximum (LGM) approximately 13,000 years before present (BP), the exposed, glacially scoured basin gradually filled with glacial melt water. The sediments deposited at this time contain hyposaline-freshwater diatom assemblages. While the Vestfold Hills were undergoing isostatic rebound, approximately 8,000-9,000 years BP, relative sea level rise occurred, allowing incursion of seawater over a sill that separated the lake basin from the sea. These incursions were probably seasonal, occurring during the summer melt phase. An annual ice cover ranging between 1.5 and $2 \mathrm{~m}$ would have precluded flow in winter.

It is likely that the original freshwater was replaced by saline water fairly rapidly, perhaps in a matter of years. Sediments laid down during this phase contain diatoms of marine planktonic and sea-ice origin. In addition, copepod eggs and skeletal remains, the testate marine ciliate, Magnifolliculina sp, and tintinnid ciliate loricae have been observed in these sediments. At this time, the lake was probably meromictic. Increasing relative sea level rise gradually transformed the lake into a marine basin with typical marine plankton, sea-ice diatoms and marine animal and protist remains deposited in the sediment. During this period (approximately 9,000-5,700 years BP), the 
Table 1 Position of the chemocline and the salinity of the water column in Ace Lake over 26 years

\begin{tabular}{|c|c|c|}
\hline Sampling date & $\begin{array}{l}\text { Position of the } \\
\text { chemocline }\end{array}$ & $\begin{array}{l}\text { Salinity-practical salinity } \\
\text { units (psu) }\end{array}$ \\
\hline Nov $1977^{\mathrm{b}}$ & $7-9 \mathrm{~m}$ & \\
\hline $\begin{array}{l}\text { Jan 1979-Dec } \\
1979^{\mathrm{c}}\end{array}$ & $6-9 \mathrm{~m}$ & $\begin{array}{l}\text { Winter mix } 19.9 \text { mono } 31.0 \\
\text { Summer mix } 15.0 \text { mono } \\
32.1\end{array}$ \\
\hline $\begin{array}{l}\text { Nov 1992-June } \\
1994^{\mathrm{d}}\end{array}$ & $7-12 \mathrm{~m}$ & Mix and mono $17.4-40.1$ \\
\hline Nov $1992^{\mathrm{e}}$ & $8-11 \mathrm{~m}$ & Mix and mono 17.1-39.2 \\
\hline $\begin{array}{l}\text { Nov } 1992^{\mathrm{f}} \\
\text { Oct } 1994^{\mathrm{g}}\end{array}$ & $7.5-9 \mathrm{~m}$ & $\begin{array}{l}\text { Mix and mono } 15.0-35.0 \\
\text { Mix and mono } 16.0-29.8\end{array}$ \\
\hline $\begin{array}{l}\text { Nov-Feb } \\
1999 / 2000^{\mathrm{h}}\end{array}$ & & Mix 18.9-19.9 \\
\hline $\begin{array}{l}\text { Dec-Feb } \\
1995 / 1997^{i, j}\end{array}$ & $\begin{array}{l}7-12 \mathrm{~m} \text { first } \\
\text { summer } \\
9-12 \mathrm{~m} \text { winter } \\
8-10 \mathrm{~m} \text { second } \\
\text { summer }\end{array}$ & $\begin{array}{l}\text { Summer mix } 11.2^{\text {a }} \text { to } 19.9 \text {, } \\
\text { mono } 37.9 \\
\text { Winter mix } 19.9-20.9 \text {, } \\
\text { mono } 38.9\end{array}$ \\
\hline $\begin{array}{l}\text { Feb-Feb } \\
2001 / 2002^{\mathrm{k}}\end{array}$ & $\begin{array}{l}10-12 \mathrm{~m} \text { in first } \\
\text { summer } \\
11-14 \mathrm{~m} \text { in winter } \\
11-14 \mathrm{~m} \text { in second } \\
\text { summer }\end{array}$ & $\begin{array}{l}\text { Summer mix } 17.4-19.9 \text {, } \\
\text { mono } 39.2 \\
\text { Winter mix } 18.9-20.9 \text {, } \\
\text { mono } 39.2\end{array}$ \\
\hline $\begin{array}{l}\text { Dec-Dec } \\
2002 / 2003^{1}\end{array}$ & $\begin{array}{l}8-12 \mathrm{~m} \text { in first } \\
\text { summer } \\
10-12 \mathrm{~m} \text { in winter } \\
10-12 \mathrm{~m} \text { in second } \\
\text { summer }\end{array}$ & $\begin{array}{l}\text { Summer mix } 15.0-20.9 \text {, } \\
\text { mono } 38.9 \\
\text { Winter mix } 19.9-20.9 \text {, } \\
\text { mono } 39.2\end{array}$ \\
\hline
\end{tabular}

mix Mixolimnion, mono monomolimnion

${ }^{\text {a }}$ Immediately under ice

b Hand and Burton (1981)

c Burch (1988)

${ }^{d}$ Rankin et al. (1999)

e Roberts and McMinn (1996)

${ }^{f}$ Gibson (1999)

g Perris and Laybourn-Parry (1997)

${ }^{\mathrm{h}}$ Laybourn-Parry et al. (2002)

${ }^{i}$ Bell (1998)

j Bell and Laybourn-Parry (1999)

${ }^{\mathrm{k}}$ Unpublished data and Laybourn-Parry et al. (2005)

${ }^{1}$ Unpublished data and Madan et al. (2005)

presence of sedimentary animal and protist remains is reduced, but diversity is higher, possibly as a result of either lower productivity or greater grazing pressure that reduced the number of remains. A subsequent reduction in relative sea level once again transformed the lake into a seasonally isolated marine basin, which eventually became completely isolated from the sea by isostatic rebound approximately 5,100 years BP. Ace Lake is thought to have stabilized in its present, stratified condition approximately 3,800 years ago (Fulford-Smith and Sikes 1996). Over the intervening time, meltwater inputs to the lake have decreased and concomitantly lake level has decreased through evaporation leading to the physicochemical status we observe today. Present day Ace Lake is meromictic and saline and located less than $200 \mathrm{~m}$ from the nearest marine inlet, Long Fjord, separated by a sill only marginally (ca. $2 \mathrm{~m}$ ) above the current lake level (FulfordSmith and Sikes 1996; Cromer et al. 2005).

\section{The physical and chemical environment}

Ace Lake has a maximum reported depth of between 23 and $25 \mathrm{~m}$ and an area of $0.13-0.18 \mathrm{~km}^{2}$ (Hand and Burton 1981; Gibson 1999). It is fed by snow melt, which varies annually depending on the amount of precipitation. Bathymetric surveys conducted in 1978 and 1991 indicate that the lake increased in area and depth over a 13-year period (Burton 1980; Gibson and Burton 1996; Dartnall 2000).

The salinity of Ace Lake increases with depth, with a series of haloclines occurring within the water column (Gibson and Burton 1996; Gibson 1999) and, in common with other meromictic lakes, salinity is the major factor maintaining the permanent stratification of the lake. The upper water column, or mixolimnion, has a salinity that ranges from approximately 11.2-20.9 psu (Table 1). In the austral summer, meltwater inflows and the melting of the lake's ice cover dilute the upper waters of the mixolimnion creating a lens of fresher water (Fig. 2). A prominent halocline and associated thermocline persist at approximately $8 \mathrm{~m}$, and below this, the waters of the upper monomolimnion become increasingly saline with depth (Fig. 2).

Salinity variations over a 26 -year period are shown in Table 1. In the mixolimnion, much of the variation will be related to the levels of snow meltwater entering the lake during summer, and the degree to which the ice cover breaks out. The inflow and melt of the ice cover dilute the lake waters. The amount of water entering the lake each year has an impact on the position of the chemocline which shows some variation over the decades, and is probably related to the increased depth and area of the lake outlined above.

Similarly, temperature varies markedly between lake strata; during the austral winter, temperatures in the mixolimnion range between -1 and $1{ }^{\circ} \mathrm{C}$ but increase sharply over the halo/thermocline (ca. $8 \mathrm{~m}$ ) to up to $6{ }^{\circ} \mathrm{C}$ in the monimolimnion (Fig. 2) (Bell and Laybourn-Parry 1999). The higher temperatures of the monimolimnion compared with those of the mixolimnion are the result of solar energy being stored at depth and stabilized by the 
Fig. 2 Water column profiles for oxygen $(\mathrm{O})$, salinity (psu) and temperature $(\mathrm{T})$ for Ace Lake in winter and in summer (under ice-free conditions) from Bell and Laybourn-Parry (1999), with the permission of Blackwell Science Ltd
Salinity (psu)

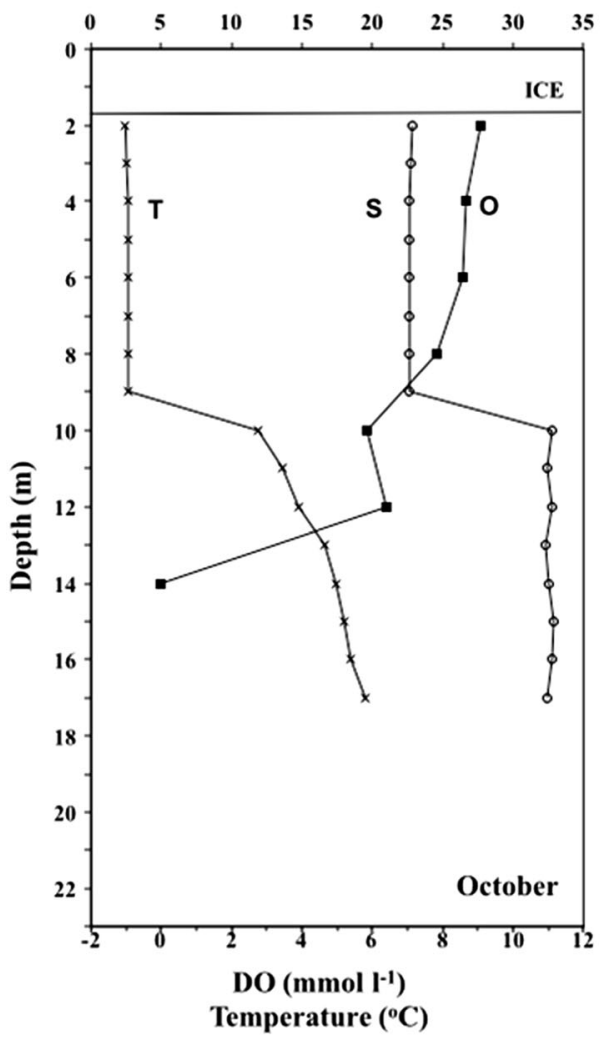

Salinity (psu)

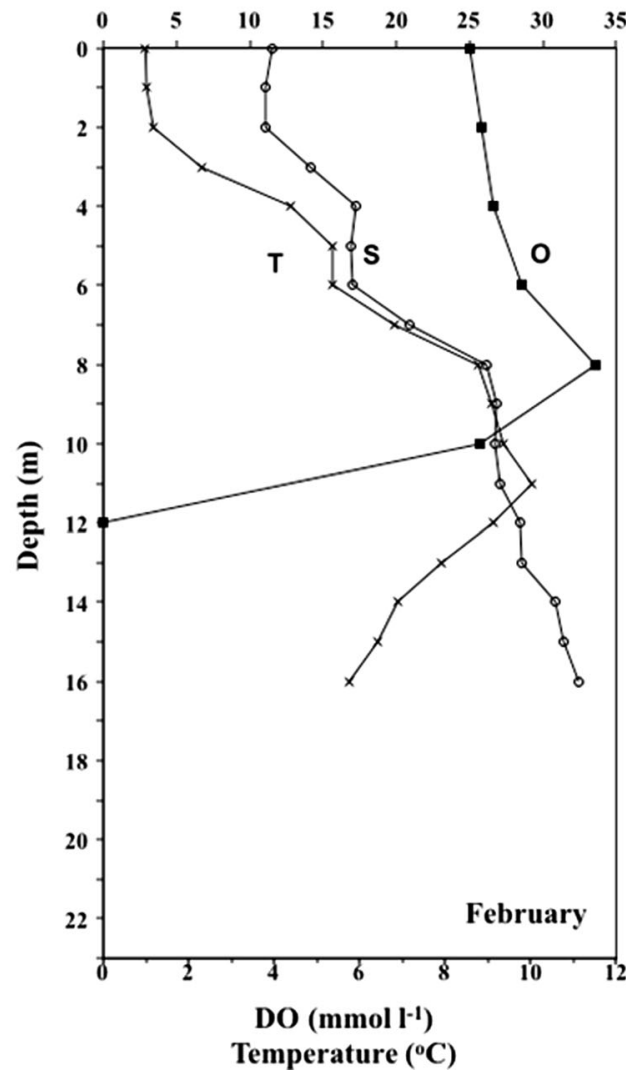

salinity gradients in Ace Lake. Similar temperature profiles are observed in other southern and northern polar meromictic lakes (Wilson et al. 1974; Spigel and Priscu 1998; Vincent et al. 2008a, b).

During the austral summer, water column temperatures vary depending on the degree to which the ice cover melts out. In years when Ace Lake becomes totally ice free, as was the case in the summer of 1995/1996, the temperature of the mixolimnion increases dramatically, e.g. up to $9{ }^{\circ} \mathrm{C}$ in February 1996 (Bell and Laybourn-Parry 1999). In other years, such as 1999/2000, the ice thins but does not completely disappear, resulting in lower maximum temperatures in the mixolimnion, e.g. between -0.8 and $2.1{ }^{\circ} \mathrm{C}$ between November 1999 and February 2000 (Laybourn-Parry et al. 2002). Similarly, in the austral summer of 2001/2002 when the lake largely retained a thinned ice cover, and only a peripheral moat of open water formed, mixolimnion temperatures ranged from $-0.9^{\circ} \mathrm{C}$ in November 2001 to $3.3{ }^{\circ} \mathrm{C}$ in February 2002 (Madan et al. 2005). These inter-annual variations in summer temperatures have a significant influence on productivity (Laybourn-Parry and Wadham 2014).

There are few time series data sets on concentrations of nutrients (ammonium, nitrate and soluble reactive phosphorus) and dissolved organic carbon (DOC) for Ace Lake. Most articles report a single datum or a mean for each nutrient, which tells us little about nutrient fluxes. Where such information is collected over annual cycles or for an entire summer there do appear to be inter-annual variations (Table 2). These variations are probably related to levels of primary and secondary production and biogeochemical cycling, which in turn are controlled by environmental factors such as the degree of summer ice cover, water temperatures and weather conditions determining levels of photosynthetically active radiation (PAR). The mixolimnion can become nutrient limiting for phytoplankton production in summer with $\mathrm{NH}_{4}-\mathrm{N}, \mathrm{NO}_{3}-\mathrm{N}$ and $\mathrm{PO}_{4}-\mathrm{P}$ falling below the limits of detection and DOC falling to around $4 \mathrm{mg} \mathrm{L}^{-1}$. Nutrients in the mixolimnion are replenished by biogeochemical cycling and by diffusion upwards from the monimolimnion over the chemocline.

The lower waters of the monimolimnion in Ace Lake are permanently anoxic, and a chemocline/oxycline is apparent in the example shown at a depth of approximately $11 \mathrm{~m}$ (Fig. 2); no oxygen is measurable below $12 \mathrm{~m}$. These increasingly anoxic waters contain high concentrations of ammonium $\left(\mathrm{NH}_{4}-\mathrm{N}\right)$ ranging between not detectable up to $503 \mu \mathrm{g} \mathrm{L}{ }^{-1}$, orthophosphate $\left(\mathrm{PO}_{4}-\mathrm{P}\right)$ ranging between 9.4 and $332 \mu \mathrm{g} \mathrm{L}^{-1}$ and DOC between 6.5 and $14.2 \mathrm{mg} \mathrm{L}^{-1}$ over an annual cycle (Bell and Laybourn-Parry 1999). 
Table 2 Mean concentrations (with SD) of ammonium, nitrate, soluble reactive phosphorus and dissolved organic carbon in the mixolimnion of Ace Lake between 1995 and 2003

\begin{tabular}{|c|c|c|c|c|}
\hline Dates & Ammonium $\left(\mu \mathrm{g} \mathrm{L}^{-1}\right)$ & Nitrate $\left(\mu \mathrm{g} \mathrm{L}^{-1}\right)$ & $\operatorname{SRP}\left(\mu \mathrm{g} \mathrm{L}^{-1}\right)$ & $\mathrm{DOC}\left(\mathrm{mg} \mathrm{L}^{-1}\right)$ \\
\hline \multicolumn{5}{|c|}{$1995-1996^{a, b}$} \\
\hline Summer & $0.99 \pm 0.68$ & $0.37 \pm 0.5$ & $11.56 \pm 17.1$ & $6.1 \pm 1.9$ \\
\hline Winter & $22.2 \pm 27.4$ & ND & $31.75 \pm 22.2$ & $7.3 \pm 0.9$ \\
\hline Summer & $0.66 \pm 0.74$ & ND & $33.68 \pm 27.6$ & $7.9 \pm 2.4$ \\
\hline \multicolumn{5}{|c|}{$1999-2000^{\mathrm{c}}$} \\
\hline Summer & $53.7 \pm 33.3$ & $40.7 \pm 33.4$ & $53.4 \pm 3.1$ & $9.1 \pm 6.5$ \\
\hline \multicolumn{5}{|c|}{$2001-2002^{\mathrm{d}}$} \\
\hline Winter & $14.7 \pm 7.6$ & $5.6 \pm 4.1$ & $41.1 \pm 7.5$ & - \\
\hline Summer & $63.9 \pm 14.8$ & $3.6 \pm 2.9$ & $22.4 \pm 8.6$ & - \\
\hline \multicolumn{5}{|c|}{$2002-2003^{e, f}$} \\
\hline Summer & $7.1 \pm 3.1$ & $5.8 \pm 1.7$ & $26.3 \pm 5.6$ & $5.1 \pm 0.7$ \\
\hline Winter & $15.2 \pm 11.5$ & $80.2 \pm 39.1$ & $27.7 \pm 4.0$ & $11.3 \pm 5.0$ \\
\hline Summer & $25.3 \pm 21.9$ & $48.0 \pm 27.6$ & $25.1 \pm 8.5$ & $6.7 \pm 4.2$ \\
\hline
\end{tabular}

Winter = June, July, August, summer = November, December, January, February. The references given are those during which these data were collected but they do not appear in detail in the articles

ND not detectable

a Bell (1998)

b Bell and Laybourn-Parry (1999)

c Laybourn-Parry et al. (2002)

d Laybourn-Parry et al. (2005)

e Madan et al. (2005)

${ }^{\mathrm{f}}$ Laybourn-Parry et al. (2007)

Methane is found in the monimolimnion between the bottom of the chemocline/oxycline and the deepest point in the lake. Methane concentrations ranging between 0 and $4.93 \mathrm{mmol} \mathrm{L}^{-1}$ were recorded in this stratum during December 1987 until the end of January 1988, with highest concentrations occurring in the anoxic bottom waters. Franzmann et al. (1991b) measured methanogenesis from $\mathrm{CO}_{2}$ reduction at $12,17,20,22$ and $24 \mathrm{~m}$. The maximum rate was $2.5 \mu \mathrm{mol} \mathrm{kg}{ }^{-1}$ of anoxic water day ${ }^{-1}$ at $1.0{ }^{\circ} \mathrm{C}$ at $20 \mathrm{~m}$, which equates to a turnover rate of 2 years at this depth. Rates were lower at the other depths giving longer turnover times. These rates are low in comparison with rates measured in freshwater Sombre Lake in the maritime Antarctic and lakes at lower latitudes (Ellis-Evans 1984; Franzmann et al. 1991b).

Sulphide concentrations in the monimolimnion of Ace Lake also increase with depth below the chemocline to around $15 \mathrm{mmol} \mathrm{L}^{-1}$ at $24 \mathrm{~m}$. Concentrations of sulphate have been shown to increase in the mixolimnion to around $6.5 \mathrm{mmol} \mathrm{L}^{-1}$, thereafter decreasing through the monimolimnion to undetectable at $21 \mathrm{~m}$ (Franzmann et al. 1988). Earlier data for 1974 showed similar sulphate concentrations of 5.8-6.5 $\mathrm{mmol} \mathrm{L}^{-1}$ in the mixolimnion decreasing in the monimolimnion to $0.09 \mathrm{mmol} \mathrm{L}^{-1}$ at $20 \mathrm{~m}$ to below the limit of detection at $22 \mathrm{~m}$ (Burton and Barker 1979).
The depletion below $21 \mathrm{~m}$ is attributed to methanogenesis (Hand and Burton 1981).

PAR is attenuated by ice cover. Snow, which strongly attenuates PAR, does not tend to accumulate to appreciable depths on the lake's ice cover because it is blown off by katabatic winds that flow down from the continental ice sheet. During April to January 2001/2002, between 11 and $77 \%$ of surface PAR penetrated to the water immediately under the ice (Laybourn-Parry et al. 2005). In 1979, between 0.03 and $55 \mu \mathrm{mol} \mathrm{m}{ }^{-2} \mathrm{~s}^{-1}$ penetrated to $5 \mathrm{~m}$ under ice, while under ice-free conditions $245 \mu \mathrm{mol} \mathrm{m}{ }^{-2}$ $\mathrm{s}^{-1}$ reached $5 \mathrm{~m}$ (Burch 1988). Thus, in summers when the ice cover is lost, PAR in the water column and, concomitantly, temperatures are elevated.

\section{Community structure}

Ace Lake supports four main biological communities: a planktonic community in the oxygenated euphotic zone of the mixolimnion; a microbial community in the anoxic monimolimnion; a benthic algal mat community supported within the littoral zone above the depth of the chemocline and a benthic community on and in the sediment below the chemocline. The upper zone of the chemocline separating 
Fig. 3 Isopleths of chlorophyll a $\left(\mu \mathrm{g} \mathrm{L}^{-1}\right)$ in Ace Lake between December 1995 and February 1997. ${ }^{+}$denotes sampling points. From Bell and Laybourn-Parry (1999), with the permission of Blackwell Science Ltd

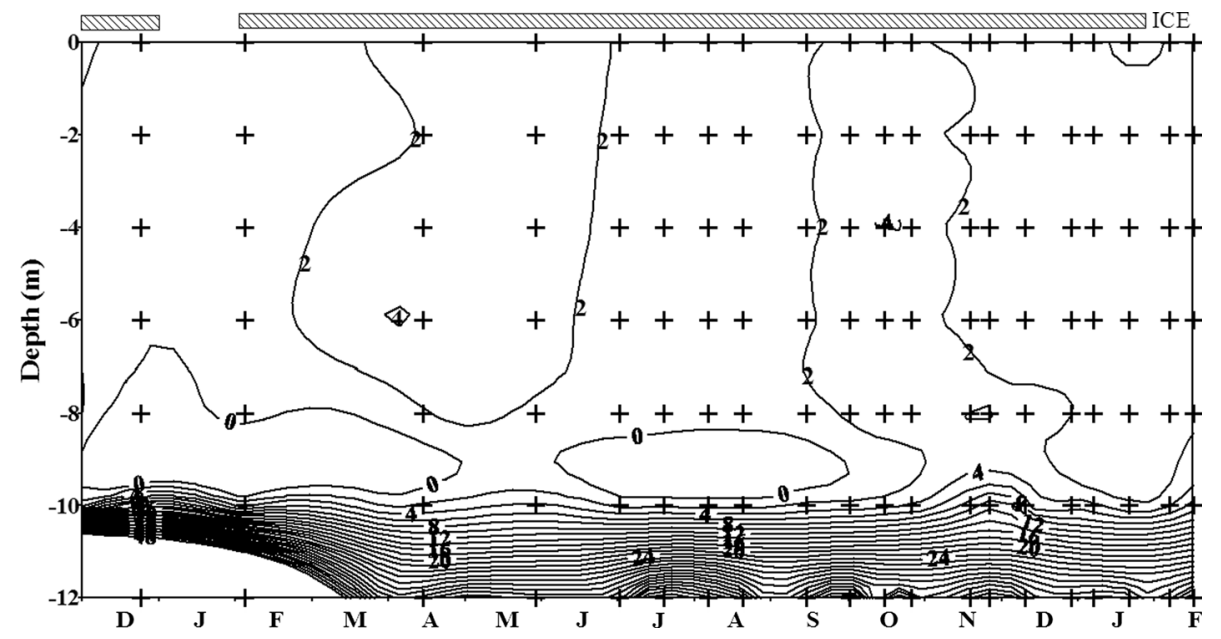

the mixolimnion and monimolimnion is a site of elevated plankton activity and a deep chlorophyll maximum (DCM) (Fig. 3). Here, oxygen diminishes (Fig. 2) and nutrient concentrations are relatively high as a result of upwards diffusion from the monimolimnion.

The planktonic mixolimnion community-in common with all Antarctic lakes, the mixolimnion of Ace Lake supports a truncated planktonic food web dominated by microorganisms with few metazoans when compared with a typical marine community (Fig. 4) (Vincent et al. 2008a, b). The only planktonic crustacean observed is the marine copepod, Paralabidocera antarctica (Wright and Burton 1981). However, Ace Lake's lacustrine population exhibits dwarfism compared with its marine ancestors; adult lengths are only $40 \%$ of counterparts in marine populations (Swadling et al. 2000). Copepodids, adults and nauplii occur in the population throughout the year, suggesting that development continues in winter (Bell and Laybourn-Parry 1999), although biomass is much reduced at this time (Table 3). Small numbers of rotifers (Encentrum spatitium, Encentrum salinum and Notholca sp.) are occasionally seen in the plankton (Bell and Laybourn-Parry 1999; LaybournParry unpublished data), but are fundamentally benthic associated with littoral algal mats (Dartnall 2000).

Detailed annual studies show that the phytoplankton in the mixolimnion is dominated by photosynthetic nanoflagellates (PNAN), particularly the cryptophyte, Geminigera cryophila, and the prasinophyte, Pyraminomas gelidicola (Burch 1988; Bell and Laybourn-Parry 1999; LaybournParry et al. 2005; Bell unpublished data). They range in abundance between $50 \times 10^{4}$ and $500 \times 10^{4}$ cells L $^{-1}$ throughout the year, with highest abundances recorded at the DCM situated on the upper chemocline at approximately $10 \mathrm{~m}$ in depth. Effectively, the PNAN are making a trade-off between access to inorganic nutrients and the availability of light, the chemocline providing high concentrations of nutrients but low PAR.

Molecular analysis of two plankton samples collected during December 2006 revealed the presence of the phytoflagellate, Mantoniella sp. (Lauro et al. 2011). The picocyanobacterium, Synechococcus sp., occurs in the plankton, being most abundant in the DCM with lowest abundance in winter increasing in summer to $<10^{7}$ $8 \times 10^{9}$ cells L $^{-1}$ (Rankin et al. 1997; Powell et al. 2005). Cryptophytes, Pyraminomas sp. and Synechococcus sp. are also major components of the plankton in the meromictic lakes of the McMurdo Dry Valleys (Vincent and Vincent 1982; Spaulding et al. 1994; Roberts et al. 2000; Bielewicz et al. 2011). Cryptophytes and P. gelidicola are mixotrophic in Ace Lake, other Vestfold Hills saline lakes and in Lakes Fryxell, Hoare and Bonney in the Dry Valleys, ingesting bacteria and/or taking up dissolved organic carbon (Marshall and Laybourn-Parry 2002; Laybourn-Parry et al. 2005; Thurman et al. 2012). This capability enables them to remain active and survive in poor light climates during the lengthy period of darkness in the austral winter.

Within the chemocline where anoxic conditions become established, green sulphur photosynthetic bacteria (Chlorobium spp.) are abundant and replace eukaryotic phototrophs (Burke and Burton 1988; Volkman et al. 1988). These bacteria are strict anaerobes.

Marine-derived dinoflagellates are a conspicuous component of the phytoplankton of saline marine-derived lakes in the Vestfold Hills, in contrast to their paucity in the Antarctic Dry Valley lakes, which are older and have a much more complex history having been derived from large proglacial lakes (Chinn 1993; Hendy 2000; Hall and Denton 2000). The dinoflagellates of the saline lakes of the Vestfold Hills display varied nutritional behaviours including autotrophic, mixotrophic and heterotrophic 


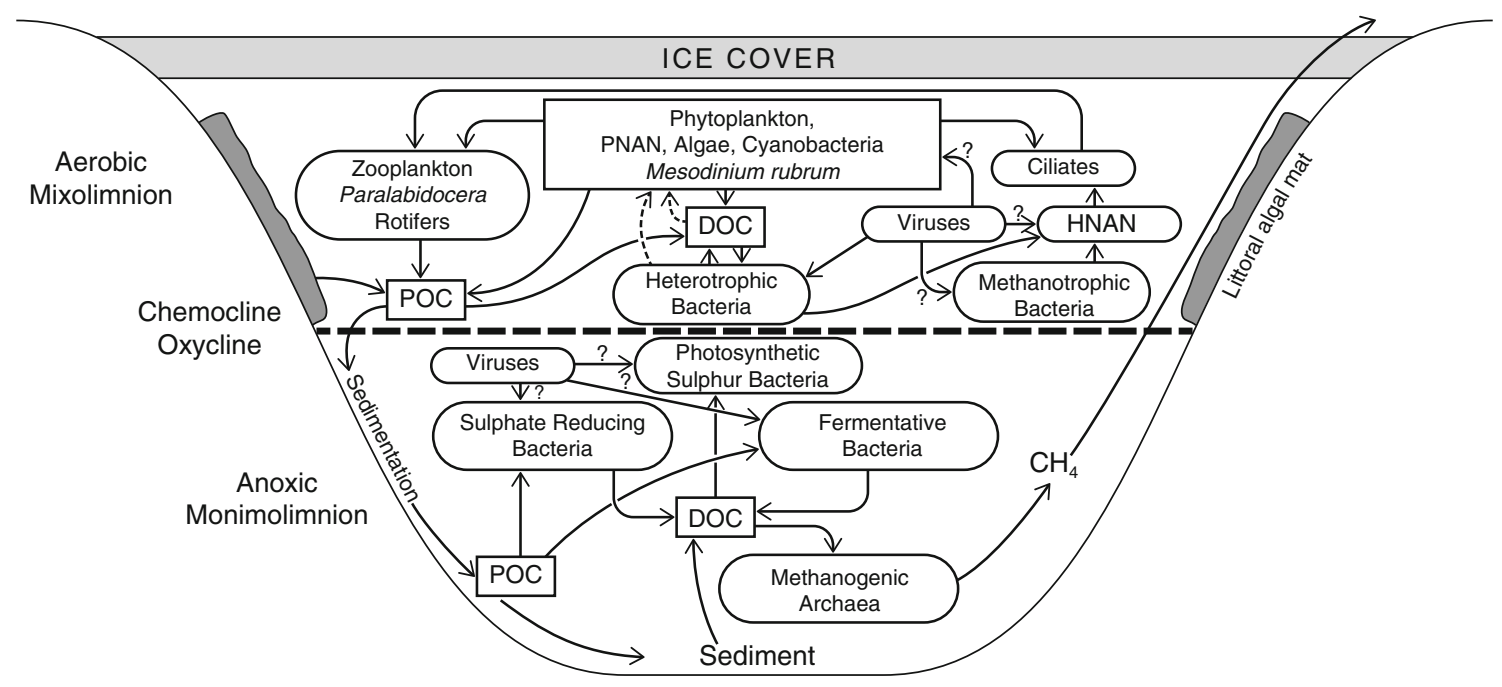

Fig. 4 The structure of communities in Ace Lake, modified from Rankin et al. (1999), with the permission of Oxford University Press

Table 3 Biomass values in $\mu \mathrm{g}$ $\mathrm{C} \mathrm{L}^{-1}$ for the elements of the Ace Lake mixolimnion community during December 1995 to February 1997
Mesodinium rubrum is part of the phytoplankton, the column for ciliates relates to other ciliates. From Bell (1998)

HNAN heterotrophic nanoflagellates, PNAN autotrophic nanoflagellates

\begin{tabular}{|c|c|c|c|c|c|c|}
\hline Season & Phytoplankton & & Heterotrophic bacteria & HNAN & Ciliates & Zooplankon \\
\hline \multirow[t]{6}{*}{ Winter } & M. rubrum & 0.06 & 27.25 & 11.08 & 0.01 & 0.59 \\
\hline & PNAN & 0.23 & & & & \\
\hline & Diatoms & 0 & & & & \\
\hline & Dinoflagellates & 0.04 & & & & \\
\hline & Picocyanobacteria & 0.79 & & & & \\
\hline & Total & 1.12 & & & & \\
\hline \multirow[t]{6}{*}{ Spring } & M. rubrum & 1.31 & 10.48 & 3.32 & 0.02 & 1.43 \\
\hline & PNAN & 2.44 & & & & \\
\hline & Diatoms & 0.03 & & & & \\
\hline & Dinoflagellates & 1.19 & & & & \\
\hline & Picocyanobacteria & 0.21 & & & & \\
\hline & Total & 5.18 & & & & \\
\hline \multirow[t]{6}{*}{ Summer } & M. rubrum & 22.82 & 12.20 & 9.58 & 5.88 & 10.78 \\
\hline & PNAN & 4.68 & & & & \\
\hline & Diatoms & 0.07 & & & & \\
\hline & Dinoflagellates & 3.45 & & & & \\
\hline & Picocyanobacteria & 0.68 & & & & \\
\hline & Total & 31.7 & & & & \\
\hline \multirow[t]{6}{*}{ Autumn } & M. rubrum & 0.41 & 15.5 & 10.69 & 0.12 & 1.32 \\
\hline & PNAN & 0.32 & & & & \\
\hline & Diatoms & 0 & & & & \\
\hline & Dinoflagellates & 0.11 & & & & \\
\hline & Picocyanobacteria & 0.13 & & & & \\
\hline & Total & 0.97 & & & & \\
\hline
\end{tabular}

species. In Ace Lake, the dinoflagellate community is dominated by Gyrodinium glaciale and Gymnodinium spp. with low numbers of Polarella glacialis (Rengefors et al. 2008). In both Ace Lake and neighbouring Pendant Lake, G. glaciale is common in the winter months by virtue of its heterotrophic/mixotrophic capability.
Heterotrophic nanoflagellates (HNAN) are the major grazers of bacteria in the plankton. In Ace Lake, they vary in abundance over an annual cycle between $18 \times 10^{4}$ and $428 \times 10^{4} \mathrm{~L}^{-1}$ (Bell and Laybourn-Parry 1999; LaybournParry et al. 2005; Madan et al. 2005). Peak abundance and biomass patterns vary from year to year; in some cases, 
highest biomass occurs in summer, while in 1999 the highest biomass was recorded in winter and the lowest biomass in Spring (Table 3). The highest numbers are typically associated with the chemocline where bacterial biomass is high. Based on year-long studies, there appear to be considerable inter-annual variations in HNAN abundance. Unfortunately, while we have data on abundances and grazing rates of the HNAN, we have virtually no information on the taxonomic make-up of the community (Laybourn-Parry and Wadham 2014).

The ciliate community of Ace Lake and other Vestfold Hills lakes with salinities between 4 and 70 psu (seawater $35 \mathrm{psu}$ ) is dominated by the autotrophic ciliate Mesodinium rubrum (Perriss and Laybourn-Parry 1997). This marine ciliate species occurs in seas and estuaries worldwide where it occasionally forms red tides. It lacks a cell mouth or cytostome and derives all of its nutrition from a cryptophycean endosymbiont (Lindholm 1985). However, some investigators have shown that at least some members of the Mesodinium complex sequester plastids from cryptophycean prey (Gustafson et al. 2000). In the mixolimnion of Ace Lake, M. rubrum can reach concentrations of up to $6 \times$ $10^{4} \mathrm{~L}^{-1}$, but in other years numbers are lower, e.g. between 1.7 and $2.5 \times 10^{3} \mathrm{~L}^{-1}$ (Perriss et al. 1995; Bell and Laybourn-Parry 1999; Laybourn-Parry et al. 2002). As indicated in Table 3, M. rubrum makes substantial contribution to phytoplankton biomass, particularly in the summer, and can contribute up to $26 \%$ of phytoplankton photosynthesis (Laybourn-Parry and Perriss 1995). Other ciliate genera occurring in low numbers are Euplotes sp., Holophyra sp. and Monodinium sp. These species are heterotrophic feeding on bacteria, HNAN and PNAN.

Heterotrophic bacterial abundances and production have been well documented in the mixolimnion of Ace Lake (Tables 3 and 4). The highest abundances occur on the chemocline and include methanotrophic and sulphatereducing bacteria (Bowman et al. 1997; Rankin et al. 1999). In some years, there is no obvious pattern in abundance while in others peak abundances have been noted in winter (Table 3). Two samples taken on 21 and 22 December 2006 showed that Proteobacteria were a major component of the bacterioplankton at all depths, but there was shift from Alphaproteobacteria and Deltaproteobacteria in the mixolimnion to Deltaproteobacteria, Epsilonproteobacteria and Gammaproteobacteria in the monomolimnion (Lauro et al. 2011). However, at present, the seasonal succession of Bacteria and Archaea in this lake remains unknown.

The monimolimnion water column

The anoxic waters of the monimolimnion are the domain of anaerobic prokaryotes (Fig. 4). Some purple sulphur photosynthetic bacteria occur, but photosynthetic green sulphur bacteria dominate bacteriochlorophylls in the lower chemocline (Burke and Burton 1988; Rankin et al. 1999). In summer, green sulphur bacteria can reach concentrations of $10^{7}$ cells $\mathrm{L}^{-1}$ (Rankin et al. 1999). More recently, a metagenomic approach has shed more light on the functioning of green sulphur bacteria in Ace Lake $(\mathrm{Ng}$ et al. 2010); the dominant species, designated C-Ace, possess chlorosomes with extremely efficient light-capturing capabilities enabling phototrophy and growth at very low light intensities. This, coupled with their ability to grow at low temperatures is probably responsible for their dominance.

An active methane cycle in Ace Lake during the past 3,000 years is indicated from the analysis of lipids specific for methanogenic Archaea and the molecular remains of methanotrophic Bacteria (Coolen et al. (2004). Methane production in present day Ace Lake is slow (in the region of $<2.5 \mu \mathrm{mol} \mathrm{kg}^{-1} \mathrm{day}^{-1}$ ) as a result of low temperatures and slow input of organic matter; nevertheless, there is sufficient methane to support methanotrophs (Bowman et al. 1997). Indeed, methanotrophic bacteria have been isolated from present day Ace Lake and other Vestfold Hills lakes. These are a subset of a physiological group known as the methylotrophs and are unique in their ability to use methane as a sole carbon source.

During its complex history, Ace Lake has undergone several shifts in the species composition of Archaea and aerobic methanotrophic bacteria. The methanotrophs now present in Ace Lake probably colonized when the lake was a marine inlet (Coolen et al. 2004). Overall, they represent only a small fraction of total bacteria in present day Ace Lake, in the order of $<0.1-1 \%$ (Bowman et al. 1997).

A new methanotrophic bacterium, Methylosphaera hansonii, belonging to a Group 1 methanotrophic genus (Gammaproteobacteria), was isolated from both Ace Lake and Burton Lake in the Vestfold Hills (Bowman et al. 1997). Burton Lake still has a periodic connection to the sea. In Ace Lake, methane increases across the chemocline from the limit of detection at approximately $11 \mathrm{~m}$ to around $4 \mathrm{mM}$ at $23 \mathrm{~m}$. M. hansonii has been shown to reach concentrations of $4.0 \times 10^{2}$ cell $\mathrm{L}^{-1}$ on or below chemocline, increasing from $1.0 \times 10^{3}$ to $3.6 \times 10^{5}$ cells $\mathrm{L}^{-1}$ between 11 and $23 \mathrm{~m}$. Possible methanotrophs, phylotypes of Euryarchaeota, have also been identified in the deep waters of meromictic Lake Fryxell in the Dry Valleys (Karr et al. 2006).

A number of methanogenic Archaea have been isolated from the monimolimnion of Ace Lake, including Methanogenium frigidum and Methanococcoides burtonii (Franzmann et al. 1992, 1997). The biomass of methanogenic Archaea based on the identification and quantification of phospholipid-derived ether lipids (PLEL) has been 
Table 4 Means with SD and ranges of chlorophyll $a$, bacterial and primary production in the mixolimnion of Ace Lake

\begin{tabular}{|c|c|c|c|c|}
\hline $\begin{array}{l}\text { Bacterial concentration } \times \\
10^{8} \text { cells L }{ }^{-1}\end{array}$ & $\begin{array}{l}\text { Bacterial production } \\
\left(\mu \mathrm{g} \mathrm{C} \mathrm{L} \mathrm{Lay}^{-1}\right)\end{array}$ & $\begin{array}{l}\text { Chlorophyll a } \\
\left(\mu \mathrm{g} \mathrm{L}^{-1}\right)\end{array}$ & $\begin{array}{l}\text { Primary production } \\
\left(\mu \mathrm{g} \mathrm{C} \mathrm{L}^{-1} \text { day }^{-1}\right)\end{array}$ & Source and year(s) of study \\
\hline- & - & Range $<1.0-9.5$ & - & $\begin{array}{l}1979 \\
\text { Burch (1988) }\end{array}$ \\
\hline $9.76 \pm 9.30$ & $55.90 \pm 62.41$ & $1.97 \pm 0.98$ & $141.3 \pm 117.6$ & Dec 1995-Feb 1997 \\
\hline Range $1.26-72.8$ & Range $1.20-163.7$ & Range $0.3-4.4$ & Range $0-248.6$ & $\begin{array}{l}\text { Bell and Laybourn-Parry (1999), } \\
\text { Bell (1998) }\end{array}$ \\
\hline $2.78 \pm 2.10$ & $9.60 \pm 6.24$ & $0.76 \pm 0.35$ & $107.0 \pm 60.5$ & Nov 1999-Jan 2000 \\
\hline Range $1.10-7.2$ & Range 5.28-20.7 & Range $1.0-1.5$ & Range 43.4-169.2 & Laybourn-Parry et al. (2002) \\
\hline $8.91 \pm 7.91$ & - & $2.18 \pm 1.94$ & $204.7 \pm 198.4$ & Feb 2001-Feb 2002 \\
\hline Range $7.8-15.7$ & & Range $0.70-5.74$ & Range $0-770.4$ & Laybourn-Parry et al. (2005) \\
\hline $12.32 \pm 5.8$ & $36.33 \pm 27.24$ & $1.09 \pm 0.56$ & $74.83 \pm 27.24$ & Dec 2002-Dec 2003 \\
\hline Range $9.1-16.2$ & Range 4.8-74.4 & Range $0.37-1.73$ & Range 0-206.4 & $\begin{array}{l}\text { Madan et al. (2005), } \\
\text { Laybourn-Parry et al. (2007) }\end{array}$ \\
\hline
\end{tabular}

All studies apart from Laybourn-Parry et al. (2002) are year-long studies that include a winter

determined for Ace Lake (Mancuso et al. 1990). These Archaea possess unique cell membranes that consist of lipids formed with ether linkages and isoprenoid branching. A conversion factor can be applied to concentrations of PLEL to derive an estimate of biomass or cell numbers. In the monimolimnion, this equates to $<1.0 \times 10^{8}-7.4 \times 10^{8}$ cells $\mathrm{L}^{-1}$ between 17 and $23 \mathrm{~m}$ (Mancuso et al. 1990).

Sulphate-reducing bacteria are also common in the sulphate-rich waters of meromictic lakes where they reduce sulphate to sulphide by means of a number of electron donors, including $\mathrm{H}_{2}$, fatty acids, alcohols and aromatic compounds. Some ester-linked phospholipid-derived fatty acids (PLFA) are signatures for known taxa. Cell numbers of the sulphate-reducing bacteria Desulfobacter sp. and Desulfovibrio sp. in Ace Lake were determined using this method. Desulfobacter increased from $0.5 \times 10^{8}$ cell L ${ }^{-1}$ just above the chemocline at $10 \mathrm{~m}$ to $4.8 \times 10^{8}$ cells $\mathrm{L}^{-1}$ at $23 \mathrm{~m}$, while Desulfovibrio sp. was much less abundant ranging between $0.1 \times 10^{8}$ and $0.9 \times 10^{8}$ cells $\mathrm{L}^{-1}$ (Mancuso et al. 1990). It is suggested that the Grampositive, lactic acid-producing bacteria, Carnobacterium funditum and Carnobacterium alterfunditum, played a role in establishing anoxic conditions in the lake and in the supply of electron donors for sulphate-reducing bacteria (Franzmann et al. 1991a, b).

Sulphur-oxidizing bacteria obtain their energy by oxidation of reduced inorganic sulphur compounds. Some use sulphide, the sulphide being supplied as hydrogen sulphide, or as a metal sulphide such as iron or copper sulphide. Others use elemental sulphur $\left(\mathrm{S}^{0}\right)$ or thiosulphate $\left(\mathrm{S}_{2} \mathrm{O}_{3}{ }^{2-}\right)$. Some can use all three forms of sulphur. The oxygen and sulphide gradient in many meromictic lakes provide an ideal environment for sulphur-oxidizing bacteria. While there are no data for Ace Lake, strains of Thiobacillus thioparus have been isolated from the monimolimnion of Lake Fryxell. These sulphur-oxidizing bacteria were able to use thiosulphate, sulphide, elemental sulphur and thiocyanate. Highest numbers were found at $9.5 \mathrm{~m}$ where sulphide and oxygen coexist on the water column, but they were still detectable well into the anoxic monimolimnion (Sattley and Madigan 2006).

Littoral algal mats

Algal mats occur down to a depth of approximately $10 \mathrm{~m}$ in Ace Lake (Fig. 4; Hand and Burton 1981). Based on the traditional morphological analysis, the mats are composed of a matrix of Cyanobacteria including Leptolyngbya antarctica, Leptolyngbya frigida, Phormidium murrayi, Phormidium priestleyi, Oscillatoria subproboscidea and Nostoc sp. (Taton et al. 2006a). However, molecular analysis has revealed a greater diversity with a number of endemic species (Taton et al. 2006a, b). These mats are poorly developed compared with algal mats in the lakes of the nearby Larsemann Hills and pinnacle mats seen in the lakes of the McMurdo Dry Valleys (Hawes and Schwarz 1999; Hodgson et al. 2004). Nevertheless, the algal mats in Ace Lake provide a matrix for a diverse community of diatoms (Roberts and McMinn 1996, 1999) with Navicula spp., Fragilaria spp. and Stauroneis sp. being most abundant. Heterotrophic bacteria are abundant in the mats utilizing the rich source of organic carbon that they provide. Bacterial strains isolated from mats in Ace Lake and other Antarctic lakes belong to the Alphaproteobacteria, Betaproteobacteria and Gammaproteobacteria, the high and low per cent $\mathrm{G}+\mathrm{C}$ Gram-positive bacteria and the CytophagaFlavobacterium-Bacteroides, as well as numerous taxa that have not yet been sequenced (Van Trappen et al. 2002). 
The littoral sediments in water $10-30 \mathrm{~cm}$ deep also support the methanotrophic bacterium $M$. hansonii at cell concentrations of $1.6 \times 10^{6} \mathrm{~g}^{-1}$ of sediment. These cell concentrations exceed those seen in the waters of the monimolimnion (Bowman et al. 1997). Protozoa and metazoan invertebrates are abundant in the algal mats in Ace Lake, including the tube dwelling ciliate, Magnifolloculina sp., the rotifers, E. spatitium, E. salinum and Notholca sp. (see also under the planktonic mixolimnion community), a benthic harpacticoid copepod (Idomene scotti), nematodes and a platyhelminth (Rankin et al. 1999; Dartnall 2000).

The anoxic sediment

At present, we have limited data for this habitat in the Ace Lake ecosystem. A molecular study using 16S rRNA gene clone library analysis examined the community structure of the anoxic sediments (Bowman et al. 2000). Diversity in the sulphide-rich anoxic sediments was surprisingly high. Proteobacteria contributed $16 \%$ of detected clones and in Ace Lake the majority belonged to the Gamma and Delta/ Epsilon divisions. Several of the phylotypes clustered among the sulphate- and sulphur-reducing bacteria. The sulphate-reducing Desulfosarcina group was the most common and a second group of Syntrophus that are a nutritionally versatile sulphate-reducing genus. A number of archaeal phylotypes were also isolated from Ace Lake and Scale Lake, another meromictic in the Vestfold Hills. Sequence and bootstrap analysis suggests that they are roughly equidistant to the Thermoplasma division and the orders Methanomicrobiales and Halobacteriales (Bowman et al. 2000).

\section{The functional dynamics of Ace Lake}

Despite the harsh nature of the environment, annual studies have shown that a functional community exists throughout the austral winter in Ace Lake. Mixotrophic PNAN and dinoflagellates, as well as HNAN, are active year round (Bell and Laybourn-Parry 1999; Laybourn-Parry et al. 2005; Madan et al. 2005). However, the biomass of most of these groups is reduced in winter, as Table 3 shows. Bacterial production continues throughout winter and primary production occurs even when light levels are low in autumn and spring. A population of the phototrophic ciliate, $M$. rubrum, remains active in winter, but part of the population encysts, existing in spring to augment the actively growing population. The only planktonic zooplankter, the copepod $P$. antarctica, is also present in winter and does not appear to enter a resting stage or use eggs to overwinter (Bell and Laybourn-Parry 1999). The austral summer is very short, so a survival strategy that enables actively growing populations to 'hit the deck running' as summer arrives is crucial. There is insufficient time to build up numbers and biomass from resting stages or cysts. At temperate lower latitudes, there are surprisingly few studies that span icecover periods. Most investigations focus on the ice-free phase (Wetzel 2001). Ice exerts a major controlling influence on the function and dynamics of high-latitude lakes (Vincent et al. 2008a, b) and what happens in winter influences what follows in spring and summer (Salonen et al. 2009).

Primary production in the mixolimnion

Unusual among Antarctic lakes, there are a number of studies that have measured primary production in Ace Lake throughout the whole year (Table 4). Chlorophyll a concentrations varied considerably over a number of studies between 1979 and 2003 (Table 4). The highest concentrations are typical of the summer months as would be expected, but even in winter low levels of chlorophyll are measurable. At this time, photosynthesis may not be detectable, but many of the PNAN are active exploiting their mixotrophic capabilities and they retain their chlorophyll (Bell and Laybourn-Parry 2003; Laybourn-Parry et al. 2005). The variability in chlorophyll $a$ concentration and rates of photosynthesis are undoubtedly related to water temperature, PAR levels and the concentrations of $\mathrm{N}$ and P. However, it is important to bear in mind that physical and chemical conditions in 1 year can impact on subsequent years. This point is very well illustrated in data from the Dry Valleys, the largest ice-free area in Antarctica, where during the summer of 2001-2002 a very warm summer caused much greater glacial melt and inflow to the lakes. The increased turbidity reduced primary production; however, the increase in nutrients very significantly enhanced phytoplankton production in the following year. Effectively, the flood recharged the lakes with water and associated nutrients (Foreman et al. 2004). Variations in primary production and other processes are a characteristic of Antarctic lakes, and in many cases, it is difficult to explain the cause. These delicate ecosystems appear to respond quickly to local short-term climatic perturbations.

The levels of primary production achieved in Ace Lake are comparable to rates measured in other brackish and saline lakes in the Vestfold Hills (Table 4) (LaybournParry and Wadham 2014). For example, over annual cycles in Highway Lake and Pendant Lake rates ranged from 0 to 437 and 26.5 to $149 \mu \mathrm{g} \mathrm{C} \mathrm{L}^{-1}$ day $^{-1}$, respectively (Laybourn-Parry et al. 2005, 2007). These levels of production are higher than rates reported for saline lakes in the McMurdo Dry Valleys, for example, in Lake Fryxell where rates varied between undetectable to $73 \mu \mathrm{g} \mathrm{C} \mathrm{L}^{-1}$ day $^{-1}$ 
(Vincent 1981; Priscu et al. 1987), Lake Bonney where the maximum rate was $10 \mu \mathrm{g} \mathrm{C} \mathrm{L}^{-1} \mathrm{day}^{-1}$ (Priscu 1995) and Lake Vanda where the range was $0.1-1.6 \mu \mathrm{g} \mathrm{C} \mathrm{L}^{-1}$ day $^{-1}$ (Vincent and Vincent 1982). Thus, Ace Lake and other saline lakes in the Vestfold Hills are more productive than their more southerly counterparts in the Dry Valleys.

A DCM is present on the chemocline in Ace Lake (Fig. 3). The phytoplankton community in the upper layer where oxygen is still present is made up of PNAN and picocyanobacteria. The light climate is poor, but they have ready access to nutrients diffusing upwards from the nutrient-rich monimolimnion. Below this, where anoxic conditions prevail, the chlorophyll is of bacterial origin and this is the domain of photosynthetic of purple and green photosynthetic bacteria.

Among the PNAN in Ace Lake cryptophytes such as $G$. cryophilla, and the prasinophyte, $P$. gelidicola, are mixotrophic ingesting bacteria to supplement their carbon budget and/or to provide nutrients for photosynthesis (Bell and Laybourn-Parry 2003; Laybourn-Parry et al. 2005). Their ingestion rates range from $<1.0$ to 24 bacteria cell ${ }^{-1}$ day $^{-1}$. On occasion, they can equal the HNAN grazing impact on the bacterioplankton. While their numbers decline in winter, an active community is sustained through the phase of winter darkness by virtue of their nutritional versatility.

Like many other saline lakes in the Vestfold Hills, the ciliate community of Ace Lake is dominated by the autotrophic ciliate, $M$. rubrum, which is effectively part of the phytoplankton. As indicated in Sect. 3.1, in some years, it can reach high concentrations in the plankton, when it can make a significant contribution to primary production. For example, in the summer of 1993, it contributed $26 \%$ of phytoplankton primary production at $2 \mathrm{~m}$ and $15 \%$ at $8 \mathrm{~m}$ when its numbers reached between 5,600 and 13,850 cells $\mathrm{L}^{-1}$ (Laybourn-Parry and Perriss 1995).

\section{Bacterial production in the mixolimnion}

Bacterial cell concentrations in Ace Lake have been shown to vary over the years. The highest numbers recorded were in the winter of 1996 (Bell and Laybourn-Parry 1999). Bacterial production also displays considerable interannual variation (Table 4). While the data are limited, there does appear to be some correlation with rates of primary production. The highest rates of bacterial production correspond to a year with high primary production, and lowest bacterial production to a summer with low rates of carbon fixation (Table 4). Comparable rates of bacterial production occur in neighbouring saline lakes in the Vestfold Hills (Laybourn-Parry et al. 2002, 2005). However, as is the case for primary production, meromictic Ace Lake sustains higher bacterial production than the meromictic lakes of the Dry Valleys, where in Lake Bonney and Lake Fryxell summer rates were between 0 to 4.9 and 0 to $10 \mu \mathrm{g} \mathrm{C} \mathrm{L}^{-1}$ day $^{-1}$, respectively (Takacs and Priscu 1998).

Bacterial productivity is dependent on concentrations of labile dissolved organic carbon (DOC) and concentrations of $\mathrm{N}$ and $\mathrm{P}$. In Ace Lake, DOC varies from year to year, reaching a mean of $9.1 \pm 6.5 \mathrm{mg} \mathrm{L}^{-1}$ in the mixolimnion in the winter of 2003, with the lowest mean value in the summer of 2002/2003 (Table 2). Much higher concentrations of DOC are found in the nutrient-rich chemocline and monimolimnion (18.6-62 $\mathrm{mg} \mathrm{L}^{-1}$ over an annual cycle) (Laybourn-Parry unpublished data). Concentrations of DOC are relatively high in the mixolimnion. The variations seen bacterial production rates in Table 4 show no relation to DOC concentrations shown in Table 2. We have no information about the chemical make-up of the DOC pool in Ace Lake, which can affect levels of bacterial productivity (Fuhrman 1987; Chróst et al. 1989).

Viruses have been shown to play a major role in recycling carbon in freshwater Vestfold Hills lakes where in winter up to $60 \%$ of the carbon supplied to the DOC pool originates from viral lysis of bacteria (Säwström et al. 2007a). In freshwater Crooked Lake, the level of viral infection is high with up to $34 \%$ of bacteria being infected, although burst sizes (the number of viruses released from each bacterial cell on lysis) average only 4. At lower latitudes, levels of infection average $2.2 \%$ with much higher burst sizes (Säwström et al. 2007b). While we have no data on levels of infection or burst sizes for Ace Lake, concentrations of viruses in the mixolimnion water column remained high throughout the year, ranging between $8.9 \times 10^{9} \mathrm{~L}^{-1}$ and $61.3 \times 10^{9} \mathrm{~L}^{-1}$ with virus-to-bacterium ratios (VBR) of 30.6-80.0 (Madan et al. 2005). Given that bacterial numbers and production can be high in winter, the evidence suggests that viral lysis may also be important in contributing to carbon cycling in Ace Lake, at a time when primary production is minimal.

Protozooplankton growth and grazing rates in the mixolimnion

The major grazers of bacteria are the HNAN and mixotrophic PNAN (see above). The HNAN have been shown to remove between 13 and $92 \%$ of bacterial production day $^{-1}$ over an annual cycle, with highest grazing rates in summer. In contrast, the mixotrophic PNAN removed between 0 and $45 \%$ of bacterial production day ${ }^{-1}$ (Laybourn-Parry et al. 2005). Heterotrophic ciliates are not usually common in the saline lakes, so their grazing impact on bacteria and flagellated protozoans is probably minimal.

Low temperatures result in low specific growth rates when measured in the laboratory on freshly collected 
samples incubated at field temperatures. Ace Lake HNAN had specific growth rates of $0.096 \mathrm{day}^{-1}$ at $0{ }^{\circ} \mathrm{C}$, increasing to $0.410 \mathrm{day}^{-1}$ at $5{ }^{\circ} \mathrm{C}$ giving doubling times ranging between 6.7 and 1.7 days. At $8{ }^{\circ} \mathrm{C}$ the specific growth rates declined to a level comparable to that at $0{ }^{\circ} \mathrm{C}$, suggesting that the community is largely psychrophilic. The dinoflagellate community, which includes autotrophs, heterotrophs and mixotrophs, exhibited a specific growth rate of $0.14 \mathrm{day}^{-1}$ at $0{ }^{\circ} \mathrm{C}$ increasing to 0.52 day $^{-1}$ at $5{ }^{\circ} \mathrm{C}$ (Laybourn-Parry et al. 2000). The highest dinoflagellate abundance has been recorded in autumn and winter when G. glaciale dominates (Rengefors et al. 2008). The autotrophic ciliate, $M$. rubrum, achieved a specific growth rate of 0.18 day $^{-1}$ at $0{ }^{\circ} \mathrm{C}$, giving a doubling time of 3.8 days (Laybourn-Parry et al. 2000). In comparison, marine and lacustrine HNAN at lower latitudes that experience higher temperatures of between 5 and $15{ }^{\circ} \mathrm{C}$ have specific growth rates that range between 0.041 and 2.16 day $^{-1}$ with doubling times between 16.9 and 0.32 days (Bjørnsen et al. 1988; Wiesse et al. 1990; Carrick et al. 1992; LaybournParry and Walton 1998). Thus, the growth rates of Ace Lake protists overlap the range measured at lower latitudes.

\section{Future directions}

Our understanding of the community structure and functioning of the mixolimnion community of Ace Lake has expanded considerably in the past two decades. In common with other Antarctic lakes that have been subject to longterm studies, for example, the Dry Valley lakes, interannual variation is a prominent feature. This characteristic of Antarctic lakes makes both annual and detailed summer investigations particularly important. The quick-dip approach, where only a few samplings are undertaken, tells us little about seasonal patterns and successions and can lead to erroneous assertions.

Studies of benthic algal mats in the lakes of the Vestfold Hills are limited. Most studies have focused on the taxonomy of diatoms that are an important element in the community (e.g. Roberts and McMinn 1996, 1999). Process-related data are few, the exception being a study of slightly brackish Watts Lake (Heath 1988). There is much more information available about benthic mats in Dry Valley lakes and Antarctic ice shelf ponds (Quesada et al. 2008). While the mats in Ace Lake are not well developed, nonetheless studies in other lakes indicate that they may make a significant contribution to carbon cycling and there are potential important linkages between the mixolimnion and the littoral mat communities. For example, in Lake Hoare (McMurdo Dry Valleys), integrated plankton production derived from Priscu (1995) of $7.5 \mathrm{mg} \mathrm{C} \mathrm{m}^{-2}$ day $^{-1}$ in December is less than one-tenth values measured at some depths in microbial mats (Hawes and Schwarz 1999). However, in Watts Lake (Vestfold Hills), the reverse was true, and phytoplankton production was twice that measured in benthic algal mats (Heath 1988).

While we are beginning to gain an idea through molecular analysis of the taxonomy of the communities of Bacteria and Archaea that live in the anoxic monimolimnion waters, we still have very little information on processes that drive the sulphur and methane cycles, or their magnitude. An approach that combines molecular and biogeochemical investigations is beginning to shed light on these important processes in the Lake Fryxell in the Dry Valleys (Karr et al. 2003, 2006).

The highly productive zone of strong physical and chemical gradients that separates the mixolimnion and monimolimnion (the chemocline/oxycline) in meromictic lakes such as Ace Lake is also a region that demands much more detailed investigation. There are likely to be major changes in the productivity and biogeochemistry of the oxygenic phototrophs and photosynthetic bacteria that inhabit this zone over an annual cycle.

Further targeted investigations on Ace Lake may provide the opportunity to develop detailed biogeochemical models. For example, little is known of the nitrogen cycle in Ace Lake. Much more information is available for meromictic lakes in the McMurdo Dry Valleys (Priscu et al. 1987; Voyteck et al. 1999). Recent studies on high Arctic meromictic lakes have revealed that both Bacteria and Archaea show a clear vertical distribution throughout the oxic and anoxic water column and that they play a role in nitrogen cycling (Pouliot et al. 2009; Comeau et al. 2012). Given that polar lakes are increasingly recognized as sentinels of climate change (Vincent et al. 2008a, b), such models will prove invaluable in predicting longerterm changes. A multidisciplinary approach that combines biogeochemistry, the measurement of process rates (bacterial and primary production), hydrology and proteomics and metagenomics is called for. The United States National Science Foundation funded Long-Term Ecosystem Research (LTER) programme on the Dry Valley Lakes exemplifies the benefits of this holistic approach.

The study of marine-derived meromictic lakes would benefit from a comparative bipolar approach, as Ace Lake has much in common with similar marine-derived lakes in the high Canadian Arctic, for example, a large community of dinoflagellates including Polarella sp. (Charvet et al. 2012) and active over-wintering copepod populations (Van Hove et al. 2001). The Arctic lakes have two species of planktonic copepod as opposed to the single species in Ace Lake. Automated data collection to continuously monitor temperatures and PAR in the water column and ice thickness has successfully been applied in the Dry Valleys and on Crooked Lake in the Vestfold Hills (Laybourn-Parry 
and Vincent 2008). Remote sensing and automated systems offer us an invaluable opportunity to gain a much better picture of seasonal changes in the physical environment and the prediction of long-term changes.

Acknowledgments The research attributed to JL-P and EMB in this review was funded by the UK Natural Environment Research Council, the Leverhulme Trust, the European Commission, Unilever, the University of Nottingham, A SCAR Prince of Asturias Fellowship (2003/04; EMB) and the German Research Foundation (DFG). Logistic financial support was provided through the Australian Antarctic Research Assessment Committee. We are indebted to Simon Powell (Bristol University) for artwork. The authors are indebted to fellow expeditioners and colleagues, too numerous to mention, who assisted with fieldwork over many years.

Open Access This article is distributed under the terms of the Creative Commons Attribution License which permits any use, distribution, and reproduction in any medium, provided the original author(s) and the source are credited.

\section{References}

Bell EM (1998) Plankton dynamics in the saline lakes of the Vestfold Hills, Eastern Antarctica. Ph.D. dissertation, University of Nottingham

Bell EM, Laybourn-Parry J (1999) Annual plankton dynamics in an Antarctic saline lake. Freshw Biol 41:507-519

Bell EM, Laybourn-Parry J (2003) Mixotrophy in the Antarctic phytoflagellate Pyramimonas gelidicola McFadden (Chlorophyta: Prasinophyceae). J Phycol 39:644-649

Bielewicz S, Bell E, Kong W, Friedberg I, Priscu JC, Morgan-Kiss RM (2011) Protist diversity in a permanently ice-covered Antarctic Lake during the polar transition. ISME J 5:1559-1564

Bird MI, Chivas AR, Radnell CJ, Burton HR (1991) Sedimentological and stable-isotope evolution of lakes in the Vestfold Hills, Antarctica. Palaeogeogr Palaeoecol 84:109-130

Bjørnsen PK, Riemann B, Horsted SJ, Nielsen TG, Pock-Sten J (1988) Trophic interactions between heterotrophic flagellates and bacterioplankton in manipulated sea water enclosures. Limnol Oceanogr 33:409-420

Bowman JP, McCammon SA, Skerratt JH (1997) Methylosphaera hansonii gen. nov., sp. nov., a psychrophilic, group I methanotroph from Antarctic marine-salinity, meromictic lakes. Microbiology 143:1451-1459

Bowman JP, Rea SM, McCammon SA, McMeekin TA (2000) Diversity and community structure within anoxic sediment from marine salinity meromictic lakes and a coastal meromictic marine basin, Vestfold Hills, eastern Antarctica. Environ Microbiol 2:227-237

Burch MD (1988) Annual cycle of phytoplankton in Ace Lake, an ice covered, saline meromictic lake. Hydrobiologia 165:59-75

Burke CM, Burton HR (1988) Photosynthetic bacteria in meromictic lakes and stratfied fjords of the Vestfold Hills, Antarctica. Hydrobiologia 165:12-23

Burton HR (1980) Methane in a saline antarctic lake. In: Trudinger PA, Walter MR (eds) Biogeochemistry of ancient and modern environments, 3053 Australian Academy of Science Canberra, pp 243-251

Burton HR, Barker RJ (1979) Sulfur chemistry and microbiological fractionation of sulfur isotopes in a saline Antarctic lake. Geomicrobiol J 1:329-340
Carrick HJ, Fahnenstiel GL, Taylor WD (1992) Growth and production of planktonic protozoa in Lake Michigan: in situ versus in vitro comparisons and importance to food web dynamics. Limnol Oceangr 37:1221-1235

Charvet S, Vincent, WF, Comeau A, Lovejoy C (2012) Pyrosequencing analysis of the protest communities in a High Arctic meromictic lake: DNA preservation and change. Front Microbiol 3. doi:10.3389/fmicb.2012.00422

Chinn TJ (1993) Physical hydrology of the dry valley lakes. In: Green WJ, Friedman EI (eds) Physical and biogeochemical processes in Antarctic lakes, Antarctic research series 59. American Geophysical Union, Washington, DC, pp 1-51

Chróst TJ, Münster U, Rai H, Albrecht D, Witzel KP, Overbeck J (1989) Photosynthetic production and exoenzyme degradation of organic matter in the euphotic zone of a eutrophic lake. J Plankton Res 11:223-242

Comeau AM, Harding T, Galand PE, Vincent WF, Lovejoy C (2012) Microbial community structure across biogeohemial gradients in a perennially stratified Arctic Lake. Nat Sci Rep 2:604

Coolen MJL, Hopmans EC, Rijpstra IC, Muyzer G, Schouten S, Volkman JK, Damasté JS (2004) Evolution of the methane cycle in Ace Lake (Antarctica) during the Holocene: response of methanogens and methanotrophs to environmental change. Org Geochem 35:1151-1167

Cromer L, Gibson JAE, Swadling KM, Ritz DA (2005) Faunal microfossils: indicators of Holocene ecological change in a saline Antarctic lake. Palaeogeogr Palaeoecol 221:83-97

Dartnall HJG (2000) A limnological reconnaissance of the Vestfold Hills. Aust Antarct Res Exped Rep 141:1-55

Ellis-Evans JC (1984) Methane in maritime Antarctic freshwater lakes. Polar Biol 3:63-71

Foreman CM, Wolf CF, Priscu JC (2004) Impact of episodic warming events on the physical, chemical and biological relationships of lakes in the McMurdo Dry Valleys, Antarctica. Aquat Geochem 10:239-268

Franzmann PD, Skyring GW, Burton HR, Deprez PP (1988) Sulfate reduction rates and some aspects of the limnology of 4 lakes and a fjord in the Vestfold Hills, Antarctica. Hydrobiologia 165:25-33

Franzmann PD, Höpfl P, Weiss N, Tindall BJ (1991a) Psychrotrophic, lactic acid-producing bacteria from anoxic waters in Ace Lake, Antarctica: Carnobacterium funditum sp. nov. and Carnobacterium alterfunditum sp. nov. Arch Microbiol 156:255-262

Franzmann PD, Roberts NJ, Mancuso CA, Burton HR, McMeekin TA (1991b) Methane production in meromictic ace lake, Antarctica. Hydrobiologia 210:191-201

Franzmann PD, Springer N, Ludwig W, Conway de Macario E, Rohde M (1992) A methanogenic Archaeon from Ace lake, Antarctica: Methanococcoides burtoni sp nov. Syst Appl Microbiol 15:573-581

Franzmann PD, Lui Y, Balkwill DL, Aldwich HC, de Macario EC, Boone DR (1997) Methanogenium frigidum sp nov. a psychrophilic $\mathrm{H}_{2}$-utilizing methanogen from Ace Lake, Antarctica. Syst Appl Microbiol 47:1068-1072

Fuhrman J (1987) Close coupling between release and uptake of dissolved free amino acids in seawater studied using an isotope dilution approach. Mar Ecol Prog Ser 37:45-52

Fulford-Smith SP, Sikes EL (1996) The evolution of Ace Lake, Antarctica, determined from sedimentary diatom assemblages. Palaeogeor Palaeoclimatol 124:73-86

Gibson JAE (1999) The meromictic lakes and stratified marine basins of the Vestfold Hills, East Antarctica. Antarctic Sci 11:172-189

Gibson JAE, Burton HR (1996) Meromictic Antarctic lakes as indicators of climate change: the structures of Ace and Organic Lakes, Vestfold Hills, Antarctica. Pap Proc R Soc Tasman 130:73-78 
Gustafson DE, Stoecker DK, Johnson MD, Van Heukelem WF, Sneider K (2000) Cryptophyte algae robbed of their organelles by the marine ciliate Mesodinium rubrum. Nature 405:1049-1052

Hall B, Denton G (2000) Radiocarbon chronology of Ross Sea drift, eastern Taylor Valley, Antarctica: evidence for a grounded ice sheet in the Ross Sea at the last glacial maximum. Geogr Ann A 82:305-336

Hand RM, Burton HR (1981) Microbial ecology of an Antarctic saline meromictic lake. Hydrobiologia 82:363-374

Hawes I, Schwarz A-M (1999) Photosynthesis in an extreme shade environment: benthic microbial mats from lake Hoare, a permanently ice-covered Antarctic lake. J Phycol 35:448-459

Heath CW (1988) Annual primary productivity of an Antarctic continental lake: phytoplankton and benthic algal mat production strategies. Hydrobiologia 165:77-87

Hendy CH (2000) Late quaternary lakes in the McMurdo sound region of Antarctica. Geogr Ann A 82:411-432

Hodgson DA, Vyvermann W, Veleyen E, Sabbe K, Leavitt PR et al (2004) Environmental factors influencing the pigment composition of in situ benthic microbial communities in east Antarctic lakes. Aquat Microbial Ecol 37:247-263

Karr EA, Sattley MW, Jung DO, Madigan M, Achenbach LA (2003) Remarkable diversity of phototrophic purple bacteria in a permanently frozen Antarctic lake. Appl Environ Microbiol 69:4910-4914

Karr EA, Ng JM, Belchik SM, Sattley WM, Madigan MT, Achenbach LA (2006) Biodiversity of methanogenic and other Archaea in the permanently frozen Lake Fryxell, Antarctica. Appl Environ Microbiol 72:1663-1666

Lauro FM, DeMaere MZ, Yay S, Brown MV, Ng C et al (2011) An integrated study of a meromictic lake ecosystem in Antarctica. ISME J 5:879-895

Laybourn-Parry J, Perriss SJ (1995) The role and distribution of the autotrophic ciliate Mesodinium rubrum (Myrionecta rubra) in three Antarctic saline lakes. Arch Hydrobiol 135:179-194

Laybourn-Parry J, Vincent WF (2008) Future directions in polar limnology. In: Vincent WF, Laybourn-Parry J (eds) Polar lakes and rivers: limnology of Arctic and Antarctic aquatic ecosystems. Oxford University Press, Oxford, pp 307-316

Laybourn-Parry J, Wadham JL (2014) Antarctic lakes. Oxford University, Oxford

Laybourn-Parry J, Walton M (1998) Seasonal heterotrophic flagellate and bacterial plankton dynamics in a large oligotrophic lakeLoch Ness. Freshw Biol 39:1-8

Laybourn-Parry J, Bell EM, Roberts EC (2000) Protozoan growth rates in Antarctic lakes. Polar Biol 23:445-451

Laybourn-Parry J, Quayle W, Henshaw T (2002) The biology and evolution of Antarctic saline lakes in relation to salinity and trophy. Polar Biol 25:542-552

Laybourn-Parry J, Marshall WA, Marchant HJ (2005) Flagellate nutritional versatility as a key to survival in two contrasting Antarctic saline lakes. Freshw Biol 50:830-838

Laybourn-Parry J, Marshall WA, Madan NJ (2007) Viral dynamics and patterns of lysogeny in saline Antarctic lakes. Polar Biol 30:351-358

Lindholm T (1985) Mesodinium rubrum: a unique photosynthetic ciliate. Adv Aquat Microbiol 3:1-48

Madan NJ, Marshall WA, Laybourn-Parry J (2005) Virus and microbial loop dynamics over an annual cycle in three contrasting Antarctic lakes. Freshw Biol 50:1291-1300

Mancuso CA, Franzmann PD, Burton HR, Nichols PD (1990) Microbial community structure and biomass estimates of a methanogenic Antarctic lake ecosystem as determined by phospholipid analysis. Microbial Ecol 19:73-95
Marshall W, Laybourn-Parry J (2002) The balance between photosynthesis and grazing in Antarctic mixotrophic cryptophytes during summer. Freshw Biol 47:2060-2070

Ng C, DeMaere MZ, Williams TJ, Lauro FM, Raftery M, Gibson JAE, Andrews-Pfannkoch C, Lewis M, Hoffman JM, Thomas T, Cavicchioli R (2010) Metaproteogenomic analysis of a dominant green sulfur bacterium from Ace Lake. ISME J 4:1002-1019

Perriss SJ, Laybourn-Parry J (1997) Microbial communities in saline lakes of the Vestfold Hills (Eastern Antarctica). Polar Biol 18:135-144

Perriss SJ, Laybourn-Parry J, Marchant HJ (1995) The widespread occurrence of the autotrophic ciliate Mesodinium rubrum (Ciliophora: Haptorida) in the freshwater and brackish lakes of the Vestfold Hills, Eastern Antarctica. Polar Biol 15:423-428

Pouliot J, Galand PE, Lovejoy C, Vincent WF (2009) Vertical structure of Archaeal communities and the distribution of ammonia monooxygenase A gene variants in two meromictic High Arctic lakes. Environ Microbiol 11:687-699

Powell LM, Bowman JP, Skerratt JH, Franzamnn PD, Burton HR (2005) Ecology of a novel Synechococcus clade occurring in dense populations in saline Antarctic lakes. Mar Ecol Prog Ser 291:65-80

Priscu JC (1995) Phytoplankton nutrient deficiency in lakes of the McMurdo Dry Valleys, Antarctica. Freshw Biol 34:215-227

Priscu JC, Priscu LR, Vincent WF, Howard-Williams C (1987) Photosynthate distribution by microplankton in permanently icecovered Antarctic desert lakes. Limnol Oceanogr 32:260-270

Quesada A, Fernández-Valiente E, Hawes I, Howard-Williams C (2008) Benthic primary production in polar lakes and rivers. In: Vincent WF, Laybourn-Parry J (eds) Polar lakes and rivers: limnology of Arctic and Antarctic aquatic ecosystems. Oxford University Press, Oxford, pp 179-196

Rankin LM, Franzmann PD, McMeekin TA, Burton HR (1997) Seasonal distribution of picocyanobacteria in Ace Lake, a marine derived Antarctic lake. In: Battaglia B, Valencia J, Walton DWH (eds) Antarctic communities, species, structure and survival. Cambridge University Press, Cambridge, pp 178-184

Rankin LM, Gibson JAE, Franzmann PD, Burton HR (1999) The chemical stratification and microbial communities of Ace Lake: a review of the characteristics of a marine derived meromictic lake. Polarforschung 66:33-52

Rengefors K, Laybourn-Parry J, Logares R, Marshall WA, Hansen G (2008) Marine-derived dinoflagellates in Antarctic saline lakes: community composition and annual dynamics. J Phycol 44:592-604

Roberts D, McMinn A (1996) Relationships between surface sediment diatom assemblages and water chemistry gradients in saline lake of the Vestfold Hills, Antarctica. Antarct Sci 8:331-341

Roberts D, McMinn A (1999) A diatom-based palaeosalinity history of Ace Lake, Vestfold Hills, Antarctica. Holocene 9:401-408

Roberts EC, Laybourn-Parry J, McKnight DM, Novarino G (2000) Stratification and dynamics of microbial loop communities in Lake Fryxell, Antarctica. Freshw Biol 44:649-661

Salonen K, Leppäranta M, Viljanen M, Gulati RD (2009) Perspectives in winter limnology: closing the annual cycle of freezing lakes. Aquat Ecol 43:609-616

Sattley WM, Madigan MT (2006) Isolation, characterization, and ecology of cold-active, chemolithotrophic, sulfur-oxidizing bacteria from perennially ice-covered Lake Fryxell, Antarctica. Appl Environ Microbiol 72:5562-5568

Säwström C, Anesio AM, Granéli W, Laybourn-Parry J (2007a) Seasonal viral loop dynamics in two large ultra-oligotrophic Antarctic freshwater lakes. Microbial Ecol 53:1-11 
Säwström C, Granéli W, Laybourn-Parry J, Anesio AM (2007b) High viral infection rates in Antarctic and Arctic bacterioplankton. Environ Microbiol 9:250-255

Spaulding SA, McKnight DM, Smith RL, Dufford R (1994) Phytoplankton population dynamics in perennially ice-covered Lake Fryxell, Antarctica. J Plankton Res 16:527-541

Spigel RH, Priscu JC (1998) Physical limnology of the McMurdo Dry Valley lakes. In: Priscu JC (ed) Ecosystem dynamics in a polar desert: the McMurdo Dry Valleys, Antarctica, Antarctic research series 72. American Geophysical Union, Washington, DC, pp 152-188

Swadling KM, Nichols PD, Gibson JAE, Ritz DA (2000) Role of lipid in the life-cycles of ice-dependent and ice independent populations of the copepod Paralabidocera antarctica. Mar Ecol Prog Ser 208:171-182

Takacs CD, Priscu JC (1998) Bacterioplankton dynamics in the McMurdo Dry Valley lakes, Antarctica: production and biomass over four seasons. Microbial Ecol 36:239-250

Taton A, Gurbisic S, Ertz D, Hodgson DA, Piccardi R et al (2006a) Polyphasic study of Antarctic cyanobacterial strains. J Phycol 42:1257-1270

Taton A, Grubisic S, Balthasart P, Hodgson DA, Laybourn-Parry J, Wilmotte A (2006b) Biogeographical distribution and ecological ranges of benthic cyanobacteria in East Antarctic lakes. FEMS Microbiol Ecol 57:272-289

Thurman J, Parry J, Hill PJ, Priscu JC, Vick TJ, Chiuchiolo A, Laybourn-Parry J (2012) Microbial dynamics and flagellate grazing rates during transition to winter in Lakes Hoare and Bonney, Antarctica. FEMS Microbiol Ecol 82:449-458

Van Hove P, Swadling KM, Gibson JAE, Belzile C, Vincent WF (2001) Farthest north lake and fjord populations of calanoid copepods Limnocalanus macrurus and Drepanopus bungei in the Canadian high Arctic. Polar Biol 24:303-307

Van Trappen S, Mergaert J, Van Eygen S, Dawyndt P, Cnockaert MC, Swings J (2002) Diversity of 746 heterotrophic bacteria isolated from microbial mats from ten Antarctic lakes. Syst Appl Microbiol 25:603-610
Vincent WF (1981) Production strategies in Antarctic inland waters: phytoplankton ecophysiology in a permanently ice-covered lake. Ecology 62:1215-1224

Vincent WF, Vincent CL (1982) Factors controlling phytoplankton production in Lake Vanda $\left(77^{\circ} \mathrm{S}\right)$. Can J Fish Aquat Sci 39:1602-1609

Vincent AC, Mueller DR, Vincent WF (2008a) Simulated heat storage in a perennially ice-covered high Arctic lake: sensitivity to climate change. J Geophys Res Oceans. doi:10.1029/ 2007JC004360

Vincent WF, Hobbie JE, Laybourn-Parry J (2008b) Introduction to the limnology of high-latitude lake and river ecosystems. In: Vincent WF, Laybourn-Parry J (eds) Polar lakes and rivers: limnology of Arctic and Antarctic aquatic ecosystems. Oxford University Press, Oxford, pp 1-18

Volkman JK, Burton HR, Everitt DA, Allen DI (1988) Pigment and lipid composition of algal and bacterial communities in Ace Lake, Vestfold Hills, Antarctica. Hydrobiologia 165:41-57

Voyteck MA, Priscu JC, Ward BB (1999) The distribution and relative abundance of ammonia-oxidizing bacteria in lakes of the McMurdo Dry Valley, Antarctica. Hydrobiologia 401:113-130

Wetzel RG (2001) Limnology: lake and river ecosystems, 3rd edn. Academic Press, San Diego

Wiesse T, Müller H, Pinto-Coelho RM, Schweizer A, Springman D, Baldringer G (1990) Response of the microbial loop to the phytoplankton spring bloom in a large prealpine lake. Limnol Oceangr 35:781-794

Wilson AT, Holdsworth R, Hendy CH (1974) Lake Vanda: source of heating. Antarct J USA 9:137-138

Wright SW, Burton HR (1981) The biology of Antarctic saline lakes. Hydrobiologia 82:319-338

Zwartz D, Bird M, Stone J, Lambeck K (1998) Holocene sea-level change and ice-sheet history in the Vestfold Hills, East Antarctica. Earth Planet Sci Lett 155:131-145 